\title{
IMPLEMENTASI METODE BERMAIN PERAN, DISKUSI DAN PENUGASAN UNTUK PENINGKATAN HASIL BELAJAR KEWIRAUSAHAAN DAN SIKAP TANGGUNG JAWAB SISWA KELAS XI DI SMK NEGERI 3 METRO \\ TAHUN PELAJARAN 2011/2012
}

\author{
Oleh \\ Yusup Purwadi \\ Guru Kewirausahaan SMKN 3 Metro \\ yusuppurwadi61@gmail.com
}

\begin{abstract}
ABSTRAK
Tujuan penelitian tindakan kelas adalah mendeskripsikan perencanaan dan pelaksanaan pembelajaran kewirausahaan dengan menggunakan metode bermain peran, diskusi dan penugasan, untuk meningkatkan hasil belajar siswa kelas XI-Teknik Pemesinan dalam pembelajaran kewirausahaan di SMKN 3 Metro. Peneliti dapat menyimpulkan bahwa: 1) Penggunaan metode bermain peran pada KD mengelola konflik harus diawali dengan penugasan. Penugasan tersebut dimaksudkan untuk memberikan waktu latihan kepada para siswa menghafalkan transkrip dialog, belajar mengelola mimik sesuai dengan peran, mengembangkan dialog jika diperlukan. Setelah penampilan diadakan diskusi sebagai sarana evaluasi dengan pengembangan sikap tanggung jawab siswa. 2) Penerapan metode bermain peran, diskusi, dengan penugasan dapat meningkatkan prestasi belajar kewirausahaan mengelola konflik siswa kelas XITeknik Pemesinan. Analisis data menunjukan adanya peningkatan rata-rata hasil belajar meningkat 2,59 dari Prasiklus ke Siklus I, bermula dari 3,8 menjadi 6,4. Kemudian meningkat 1,34 dari 6,4 menjadi 7,7 pada siklus II. 3) Pemeranan telah memberikan pengalaman batin sehingga sikap tanggung jawab siswa menjadi lebih baik. Hal ini sebagaimana diperoleh hasil pengisian angket sikap tanggung jawab sebesar 95\% siswa menjadi cukup Tanggung Jawab. Pemaknaan tanggung jawab dalam bekal berwirausaha semakin tumbuh seiring dengan pemahaman bahwa kecerdasan kognitif terhadap aspek usaha saja tidak cukup, tetapi butuhkan sikap yang stabil.
\end{abstract}

Kata Kunci: Bermain Peran, Mengelola Konflik, Sikap Tanggung Jawab

\section{PENDAHULUAN}

Jiwa kepemimpinan dalam wirausaha harus dapat ditanamkan sejak awal. Dilatih dan dikembangkan melalui berbagai permasalahan aktual dalam kehidupan. Menerapkanjiwa kepemimpinanmerupakan hal yang tidak mudah.Jiwa kepemimpinan harus dipupuk dari awal untuk memiliki berbagai kemampuan yang dibutuhkan dalam mengelola usaha. Hal ini mengingat dalam proses pengelolaan usaha akan selalu muncul konflik dan berbagai kepentingan. Oleh karena itu seorang wirausahawan harus dapat mengelola konflik sedemikian rupa sehingga menjadi pemimpin yang baik dalam mengelola usaha.

Pembelajaran kewirausahaan harus dapat mengajak siswa untuk berbuat lebih 
tinggi dan menguasai materi-materi dalam pembelajaran pengelolaan konflik.

Kewirausahaan dapat dibelajarkan melalui berbagai metode pembelajaran.Keterlibatan belajar yang baik akan meningkatkan hasil belajar siswa dalam pelajaran Kewirausahaan. Siswa harus memiliki bekal yang cukup untuk dapat mengelola konflik dalam sebuah usaha sehingga tidak mengganggu produktivitas dan rencana kerja sebuah lapangan usaha.

Hasil ulangan Kewirausahaan di SMKN 3 Metro, siswa kelas XI-Teknik Pemesinan, menunjukan hasil rendah, khususnya pada kemampuan mengelola konflik.Mengelola konflik menjadi relevan dibelajarkan dengan metode bermain peran. Gabungan metode bermain peran dengan diskusi dan penugasan memberikan peluang besar terhadap upaya peningkatan peran siswa dalam pembelajaran Kewirausahaan dan meningkatkan rasa tanggung jawab.

\section{KAJIAN PUSTAKA}

\section{Hasil Belajar Kewirausahaan}

Belajar adalah perubahan yang relatif permanen dalam perilaku atau potensi perilaku sebagai hasil dari pengalaman atau latihan yang diperkuat.Belajar merupakan akibat adanya interaksi antara stimulus dan respon.Seseorang dianggap telah belajar sesuatu jika dia dapat menunjukkan perubahan perilakunya. Menurut teori ini dalam belajar yang penting adalah input yang berupa stimulus dan output yang berupa respon.Winkel (1991) menyatakan hasil belajar merupakan bukti keberhasilan atas usahanya sendiri atas usahanya sendiri dalam pembelajaran. Sedangkan menurut Djamarah (1994:26) mengatakan bahwa hasil belajar merupakan hasil penilaian pendidikan tentang kemampuan siswa setelah melakukan aktivitas belajar. Pendapat bahwa hasil belajar merupakan hasil atau perolehan yang dicapai seseorang melalui kegiatan belajar. Bloom dalam Sudjana (2001: 22) menyatakan bahwa hasil belajar ranah kognitif berkenaan dengan hasil belajar intelektual yang terdiri dari enam aspek, yakni pengetahuan atau ingatan, pemahaman, aplikasi, analisis, sintesis dan evaluasi.

\section{Sikap Tanggung Jawab Wirausahawan}

Secara garis besar jiwa kepemimpinan ini timbul akibat dari rasa tanggungjawab atas sesuatu yang dirasa harus diurus guna untuk memberikan kenyamanan bagi orang lain yang tengah kita pimpin dalam wadah kelompok untuk mencapai kemakmuran bersama dan jiwa kepemimpinan ada untuk memberikan motivasi kepada orang lain yang tengah kita pimpin. Mengatasi dan 
mengelola konflik menjadi salah satu tugas seorang wirausahawan.

Salah satu karakter yang dapat mereduksi terjadinya konflik adalah sikap tanggung jawab seseorang. Tanggung jawab adalah kesadaran manusia akan tingkah laku atau perbuatannya yang disengaja maupun yang tidak di sengaja. Tangung jawab juga berarti berbuat sebagai perwujudan kesadaran akan kewajibannya.Karena pada dasarnya, masalah terjadi ketika orang melalaikan tugas dan tanggung jawabnya. Konflik harus dapat dikelola sedemikian rupa.

Dimensi ketiga kewirausahaan adalah proaktif.Miller (1987) melihatnya sebagai bagian sifat assertif, bahwa kewirausahaan sebagaipengambil risiko dan melakukannya, ketimbang sekedar bereaksi terhadap lingkungannya.Secara ringkas, tingkat tanggung jawab seseorang merupakan kapasitas yang bersangkutan dalam memikul beban yang telah menjadi komitmen dalam dirinya meliputi 1) Menanggung akibat perbuatanya, 2) Tidak akan menyalahkan orang lain, 3) Menyadari kelemahan, 4) Berusaha memperbaiki diri, 5) Pengambilanresiko, dan 6) Proaktif.

\section{Metode PembelajaranBermain Peran}

Bermain peran merupakan cara yang penting dalam merangsang kegiatan. Melalui teknik bermain peran guru dapat mengarahkan siswa kepada pemikiran dan penggunaan bahasa yang santun dan etis. Adanya pemeranan memungkinkan peluang keterlibatan siswa dalam pembelajaran secara aktif dan bermakna, (Heaton, 1991: 102). Para siswa dapat bereksplorasi dalam pembicaraan, semisal pada penggunaan bahasa yang santun dan etis dan sering digunakan untuk berkomunikasi dengan orang lain.

Penggunaan metode bermain peran sebetulnya memang mengedepankan kerja sama antara siswa. Dengan demikian penggunaan metode ini merupakan salah bentuk pengejawantahan pembelajaran kooperatif. Pembelajaran kooperatif merupakan prosedur pembelajaran dimana para siswa bekerja sama di dalam kelompokkelompok kecil dan dihargai atas hasil yang dicapai bersama mereka, (Cruickshank et all, 2006:238). Selayaknya bermain peran masing-masing individu memerlukan kerjasama yang baik dari masing-masing pemeran untuk mendapatkan pementasan yang baik.

\section{Metode Diskusi, dan Penugasan}

a. Metode Diskusi

Metode diskusi merupakan kegiatan yang saling mempertanyakan pendapat beberapa orang terhadap suatu objek atau 
permasalahan.Metode ini bertujuan untuk tukar menukar gagasan, pemikiran, informasi/ pengalaman diantara peserta, sehingga dicapai kesepakatan pokok-pokok pikiran (gagasan, kesimpulan).Untuk mencapai kesepakatan tersebut, para peserta dapat saling beradu argumentasi untuk meyakinkan peserta lainnya.Metode diskusi merupakan cara mengajar dalam pembahasan dan penyajian materinya melalui suatu masalah atau pertanyaan yang harus diselesaikan berdasarkan pendapat atau keputusan secara bersama, (Winataputra,2005:4.14).

b. Metode Penugasan

Langkah-langkah menggunakan tugas adalah:

1) Fase Pemberian Tugas. Tugas yang diberikan kepada siswa hendaknya mempertimbangkan; tujuan yang akan dicapai, jenis tugas dan tepat, sesuai dengan kemampuan siswa, ada petunjuk yang dapat membantu dan sediakan waktu yang cukup.

2) Pelaksanaan Tugas. Diberikan bimbingan/pengawasan oleh guru.Diberikan dorongan sehingga anak mau melaksanakannya.Diusahakan atau dikerjakan oleh anak sendiri.Mencatat hasil yang diperoleh dengan baik dan sistematik.3) Fase Pertanggungjawaban Tugas.

c. Pembelajaran Kewirausahaan

Dalam suatu proses pembelajaran ada beberapa komponen yang selalu terkait dan tidak bisa dipisahkan, yaitu media pengajaran, prosedur didaktif (metode), materi pelajaran dan lain-lain. "Semua komponen tersebut harus terpadu dan serasi agar tercipta suasana belajar mengajar yang menyenangkan, akhirnya terwujud suatu hal apa yang dinamakan dengan hasil belajar yang berbobot dan berkualitas (Winkel, 1991:177). Hal yang sama juga diperlukan dalam pembelajaran mengelola konflik sebagai salah satu KD pada Kewirausahaan.

Konflik dapat diartikan sebagai ketidak setujuan antara dua atau lebih anggota organisasi atau kelompok-kelompok dalam organisasi yang timbul karena mereka harus menggunakan sumber daya yang langka secara bersama-sama atau menjalankan kegiatan bersama-sama dan atau karena mereka mempunyai status, tujuan, nilai-nilai dan persepsi yang berbeda.Anggota-anggota organisasi yang mengalami ketidaksepakatan tersebut biasanya mencoba menjelaskan duduk persoalannya dari pandangan mereka. 


\section{METODE PENELITIAN}

Penelitian dilakukan menggunakan metode PTK. Prosedurnya (1) Planning, (2) Acting, (3) Observing, (4) Reflecting ,(Arikunto, 2006: 117). Langkahnya disebut dengan siklus, dan tidak hanya cukup satu kali, jika satu siklus belum menunjukkan adanya perubahan, maka dilakukan berulang sampai ada perubahan yang diharapkan.

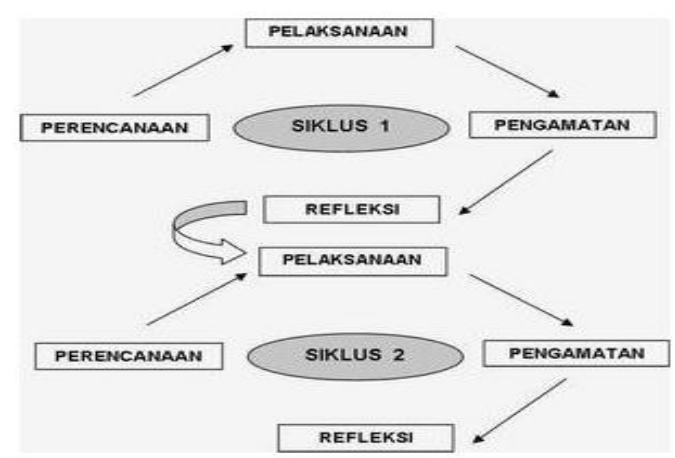

Gambar 1. Alur PTKMetode John Elliot

Pengamatan terhadap guru yang memberikan tindakan merupakan telaah untuk mempelajari langkah-langkah dalam menerapkan pembelajaran dengan metode bermain peran dengan metode diskusi dan penugasan. Siklus berikutnya atau tidak didasarkan pada hasil refleksi dan indikator ketercapaian dari siklus sebelumnya. Perencanaan indikator harus jelas dan tegas, sehingga mudah mengidentifikasi ketercapaian tujuan pada tiap siklusnya.

Penelitian ini dilaksanakan di SMK N 3 Metropada siswa kelas XI-Teknik Pemesinan Semester Ganjil Tahun Pelajaran
2011/2012.Ada 29 siswa. Dilaksanakan tiga bulan dari September sampai Oktober 2011. Pelaksanaan PTK disesuaikan dengan jadwal pembelajaran.

Indikator Keberhasilan adalah sebagai berikut:

Tabel 1. Indikator Keberhasilan

\begin{tabular}{|l|l|l|l|}
\hline $\begin{array}{c}\text { Lama } \\
\text { Tindakan } \\
(1 \text { siklus })\end{array}$ & \multicolumn{1}{|c|}{ Tujuan } & $\begin{array}{c}\text { Indikator } \\
\text { Keberhasilan }\end{array}$ & $\begin{array}{c}\text { Banyak- } \\
\text { nya }\end{array}$ \\
\hline $\begin{array}{l}\text { 2x2x45 } \\
\text { menit }\end{array}$ & $\begin{array}{l}\text { 1. Prestasi belajar } \\
\text { Kewirausahaan }\end{array}$ & $\begin{array}{l}\text { Siswa mendapatkan } \\
\text { skor } 70\end{array}$ & $75 \%$ \\
\cline { 2 - 4 } & 2. Tingkat \\
tanggung jawab & $\begin{array}{l}\text { Siswa } \\
\text { meningkatkan sikap } \\
\text { tanggungjawabnya } \\
\text { sampai pada } \\
\text { kategori sangat } \\
\text { bertanggungjawab }\end{array}$ & $75 \%$ \\
\hline
\end{tabular}

Keseluruhanpenelitian dapat terjadi dalam tiga siklus maka metode pembelajaran bermain peran diintegrasikan dengan metode diskusi pada siklus I. Tentu saja jenis metode yang digunakan pada siklus II dan seterusnya tergantung dari hasil refleksi setelah selesai dilakukan pada siklus I. Pada Siklus II metode bermain peran bisa integrasikan dengan metode diskusi dan penugasan sekaligus. Peren-canaan tersebut didasarkan pada muatan dan karakteristik materi pembelajaran dalam KD Mengelola konflik, pemberian tindakan tersebut bisa selesai dalam dua pertemuan atau lebih dengan durasi $2 \times 45$ menit setiap pertemuannya.

Instrumen penelitian sebagaimana dirumuskan dalam kisi-kisi instrumen 
sebelum-nya adalah tes hasil belajar berbentuk esai untuk mengukur ketercapaian tujuan pembelajaran pada KD. Angket digunakan untuk mengukur intensitas tanggung jawab siswa. Data bersifat kuantitatif yang telah diperoleh dianalisis menggunakan statistik deskriptif.Statistik deskriptif menggambarkan ukuran pemusatan berupa ukuran rata-rata, modus dan median dari sebaran data baik angka nominal maupun persentase.

\section{HASIL DAN PEMBAHASAN}

Tindakan penelitian dibagi dalam prasiklus, siklus I, dan siklus II. Pada prasiklus merupakan tahapan dimana pengamata selama proses pembelajaran konvensional dilakukan. Siklus I dan II merupakan pemberian tindakan. Tindakan dilaksanakan sebagai berikut:

1) Pendahuluan: a) Apersepsi, Kesiapan kelas dalam pembelajaran (absensi, kebersihan, kelas dll); b) Memotivasi. Penjajagan kesiapan belajar siswa denganmemberikan pertanyaan tentang materi yang akan diajarkan; c) Informasi kompetensi yang akan dicapai, kegiatan

2) Inti: a) Membagi siswa menjadi 8 kelompok; b) Masing-masing kelompok diberikan tugas untukuntuk mempelajari materi yang mengidentifikasikan macam- macam konflik dan perbedaannya, dan menejemen konflik; c) proses terjadinya konflik dalam suatu organisasi, badan, atau bahkan rumah tangga. Pemeranan ditampilkan dalam bentuk dialog antartokoh saat terjadi dan penyebab konflik dalam PBM diupayakan yang seaktual mungkin dan menampilkan bagaimana cara menejemen konflik; c)Masing-masing kelompok diberikan kesempatanuntuk memerankan adegan penerapan tersebut selama 7 menit; d) Kelompok lain menanggapinya.

3) Penutup: a) Dengan bimbingan guru, masing-masing wakil kelompokmemberikan refleksi terhadap peran yang telah ditampilkan; b) Mengadakan tes formatif; c) Memberikan angket sikap tanggung jawab siswa; c) Memberi tugas rumah secara kelompok mempersiapkan materi sebab timbulnya konflik dan akibat positif dan negatif, rumusan penyelesaian konflik dan pengambilan keputusan. Pemeranan ditampilkan dalam bentuk dialog antartokoh dalam usaha mengelola konflik.

Ada perubahan besarnya ukuran ratarata, simpangan baku, variansi, rentang, nilai terendah, nilai tertinggi dan jumlah dari Siklus I ke Siklus II. 
Tabel 2. Deskripsi Data Prestasi Belajar

\begin{tabular}{|l|l|l|l|l|l|}
\hline \multirow{2}{*}{ No } & \multirow{2}{*}{ Ukuran } & \multicolumn{3}{|c|}{ Prestasi Belajar } & \multirow{2}{*}{$\begin{array}{l}\text { Pening- } \\
\text { katan }\end{array}$} \\
\cline { 3 - 5 } & & Prasiklus & $\begin{array}{c}\text { Siklus } \\
\text { I }\end{array}$ & $\begin{array}{c}\text { Siklus } \\
\text { II }\end{array}$ & \\
\hline 1 & Rata-rata & 3,79 & 6,38 & 7,72 & 1,34 \\
\hline 2 & Standar Kesalahan & 0,14 & 0,09 & 0,12 & \\
\hline 3 & Nilai Tengah & 4,00 & 6,00 & 8,00 & 2,00 \\
\hline 4 & Modus & 3,00 & 6,00 & 8,00 & 2,00 \\
\hline 5 & Simpangan Baku & 0,77 & 0,49 & 0,65 & \\
\hline 6 & Variansi & 0,60 & 0,24 & 0,42 & \\
\hline 7 & Kurtosis & $-1,19$ & $-1,86$ & $-0,59$ & \\
\hline 8 & Kejulingan & 0,39 & 0,53 & 0,33 & \\
\hline 9 & Rentang & 2,00 & 1 & 2,00 & \\
\hline 10 & Nilai Terendah & 3,00 & 6 & 7,00 & 1,00 \\
\hline 11 & Nilai Tertinggi & 5,00 & 7 & 9,00 & 2,00 \\
\hline 12 & Jumlah & 110,00 & 185,0 & 224,0 & 39,00 \\
\hline 13 & Banyaknya Data & 29,00 & 29,00 & 29,00 & \\
\hline
\end{tabular}

Terdapat peningkatan hasil belajar dari Siklus I ke Siklus II. Peningkatan rata-rata terjadi sebesar 1,34 dari 6.38 pada Siklus I menjadi 7,72 pada Siklus II. Nilai terendah meningkat 1 dari 6 pada Siklus I menjadi 7 pada Siklus II. Nilai tertinggi meningkat2 dari 7 pada Siklus I menjadi 9 pada Siklus II. Kemampuan siswa kurang homogen karena variasi data pada Siklus II sedikit lebih besar dari siklus I.Data ditampilkan pada Gambar 4 di bawah ini.

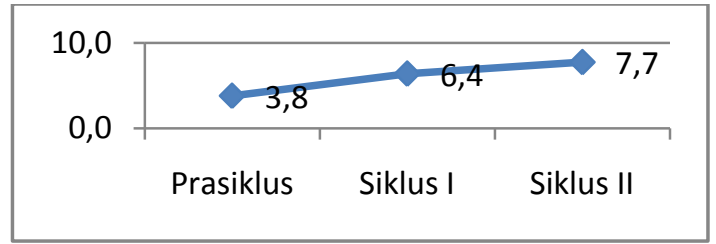

Gambar 2. Peningkatan Rata-rata Prestasi BelajarDari Prasiklus, Siklus I dan II

Rata-rata meningkat 2,59 dari Prasiklus ke Siklus I, bermula 3,8 ke 6,4. meningkat 1,34 dari 6,4 ke 7,7 siklus II. Peningkatan prasiklus, siklus I, dan II.

Seluruh aspek: 1) Menanggung akibat perbuatanya, 2) Tidak akan menyalahkan orang lain, 3) Menyadari kelemahan, 4)
Berusaha memperbaiki diri, 5) Pengambilanresiko, dan 6) Proaktif telah mengalami peningkatan dari prasiklus, siklus I, ke siklus II. Peningkatan tersebur disebabkan karena perlakuan yang telah diberikan pada siklus II. Keadaaan Tanggung Jawab siswa selama proses pembelajaran juga dapat dideskripsikan menurut predikatnya.

Tabel 3. Sebaran Butir Tanggung Jawab Siswa dalam Pembelajaran

\begin{tabular}{|c|c|c|c|c|c|c|c|c|c|c|c|c|c|}
\hline \multirow[t]{3}{*}{ Siklus } & \multicolumn{12}{|c|}{ Aspek dan Butir Tanggung Jawab Siswa } & \multirow[t]{3}{*}{$\mathrm{Jml}$} \\
\hline & \multicolumn{2}{|c|}{\begin{tabular}{|l|l}
1 & \\
\end{tabular}} & \multicolumn{2}{|l|}{2} & \multicolumn{2}{|c|}{3} & \multicolumn{2}{|l|}{4} & \multicolumn{2}{|l|}{5} & \multicolumn{2}{|l|}{6} & \\
\hline & 1 & 2 & 3 & 4 & 5 & 6 & 7 & 8 & 9 & 10 & \begin{tabular}{|l|}
11 \\
\end{tabular} & 12 & \\
\hline \multirow[t]{2}{*}{ Prasiklus } & 0 & 0 & 16 & 12 & 15 & 15 & 0 & 0 & 16 & 12 & 15 & 15 & 116 \\
\hline & 0 & 0 & 55 & 41 & 52 & 52 & 0 & 0 & 55 & 41 & 52 & 52 & \\
\hline \multirow[t]{2}{*}{ Siklus I } & 4 & 6 & 14 & 15 & 18 & 14 & 4 & 6 & 14 & 15 & 18 & 14 & 71 \\
\hline & 14 & 21 & 48 & 52 & 62 & 48 & 14 & 21 & 48 & 52 & 62 & 48 & \\
\hline \multirow[t]{2}{*}{ Siklus II } & 9 & 12 & 17 & 19 & 24 & 18 & 9 & 12 & 17 & 19 & 24 & 18 & 99 \\
\hline & 31 & 41 & 59 & 66 & 83 & 62 & 31 & 41 & 59 & 66 & 83 & 62 & \\
\hline
\end{tabular}

Peningkatan Tanggung Jawab siswa dalam pembelajaran Kewirausahaan menurut predikatnya, dapat dilihat pada gambar grafik peningkatan di bawah.

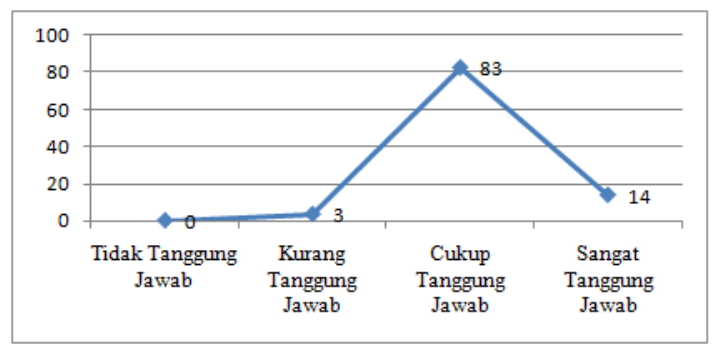

Gambar 3. Peningkatan Predikat

TanggungJawab Siswa

Predikat "Tidak Tanggung Jawab" ada 14\%,predikat "Kurang Tanggung Jawab ada 34\%.Predikat "CukupTanggung Jawab" ada 
45\%. Predikat sangat Tanggung Jawab ada 7\% pada siklus I. Predikat “Tidak Tanggung Jawab" ada $0 \%$, predikat "Kurang Tanggung Jawab ada 3\%. Predikat "CukupTanggung Jawab" ada 83\%. Predikat sangat Tanggung Jawab ada 14\% pada Siklus II.Sebesar 95\% siswa menjadi cukup Tanggung Jawab dan sangat Tanggung Jawab.

Peningkatan prestasi belajar terjadi karena kemampuan untuk memaknai peran melalui emosi muncul begitu saja. Pemaknaan terjadi karena fenomena terjadinya konflik seringkali mirip dengan apa yang diperankan. Bermain peran menjadi suatu cara penguasaan bahan-bahan pelajaran melalui pengembangan imajinasi dan penghayatan siswa.Disinilah pengembangan sikap secara intensif terjadi sebagai dampak samping sebuah proses pembelajaran yang dilaksanakan.

Dalam hal ini guru menghentikan pada saat terjadinya pertentangan agar memancing permasalahan agar didiskusikan. Konflik menejeman menjadi salah satu masalah sosial. Hal ini sebagaimana pendapat yang disampaikan bahwa, "Masalah yang muncul dari bermain peran, dibahas pada tahap diskusi dan evaluasi.Role playingdisebut juga metode sosiodrama.Sosio-drama pada dasarnya mendramatisasikan tingkah laku dalam hubungannya dengan masalah social.
Memang ada upaya guru untuk membantu siswa mengucapkan kalimatkalimat awal sebagai pembuka ketika dimulainya pemeranan. Hal ini wajar, apalagi pada siklus I, ketika "Demam Panggung", istilahnya, merasuk ke pikiran siswa yang maju pertama kali untuk menampilkan alur cerita tentang konflik tersebut. Ada praktik pengelolaan konflik, identifikasi lebih awal terhadap konflik, dan bagaimana menghindarinya jika sulit untuk dikendalikan pada saat pemerananan dilakukan. Siswa cenderung merasa senang ketika memerankan konflik dan cara pengelolaannya, karena pada dasarnya, pemeranan tersebut adalah permainan.

Peningkatan hasil belajar semakin baik pada siklus II. Adanya penugasan yang diberikan memberikan ruang dan waktu sekaligus penekanan untuk berlatih lebih mendalam pada transkrip cerita yang berkaitan dengan konflik-konflik yang terjadi dalam organisasi. Siswa boleh secara bebas membuat transkrip yang menjadi pemicu konflik, proses konflik, dan penanganan konflik dalam sebuah organisasi.

Bahkan cara-cara untuk mengatasi konflik, seperti menghindar, mengakomodasi, berkompetisi, kompromi atau negosiasi, memecahkan masalah atau 
kolaborasi, secara tidak sadar telah dipertontonkan selama penggunaan metode bermain peran. Dengan demikian menjadi sebuah kewajaran ketika prestasi belajar menangani konflik meningkat dan melebihi KKM yang ditetapkan.

Menyadari bahwa konflik selalu muncul ketika orang-orang dalam organisasi mengabaikan tugas dan kewajiban yang diberikan, maka penerapan bermain peran dengan berbagai konflik memberikan nuansa perasaan dan pemikiran bahwa tidak seharusnya seseorang menjadi sumber konflik. Kenyataan bahwa setiap individu berbeda ciri dan karakter merupakan sumber konflik yang tidak dapat dihindarkan. Bermain peran bisa membangun karakter dan menumbuhkan sifat yang baik. Hal ini sebagaimana disampaikan bahwa, "Bermain peran (role-playing) adalah strategi pengajaran yang termasuk ke dalam kelompok model pembelajaran sosial (social models). Strategi ini menekankan sifat sosial pembelajaran, dan memandang bahwa perilaku kooperatif dapat merangsang siswa baik secara sosial maupun intelektual", (Joyce and Weil, 2000).

Setelah pemeranan kemudian diadakan refleksi terkait dengan pemeranan dan pesan moral yang terkandung. Di sinilah sikap tanggung jawab ini dipupuk. Hal ini terjadi karena setiap refleksi selalu muncul kelemahan yang menjadi temuan dari pemeranan. Pemberi ide dalam kelompok, belajar untuk mengembangkan sikap tidak menyalahkan anggotanya bahkan menerima konsekuensi dari hasil tampilan pemeranan. Setelah kegiatan peragaan peran oleh siswasiswa di depan kelas, maka setiap kelompok dapat membahasnya pada diskusi kelas kegiatan ini difasilitasi oleh guru untuk mencapai tujuan pembelajaran yang diharapkan.

Keterlibatan siswa dalam setiap proses pembelajaran memberikan makna yang mendalam terhadap ketercapain tujuan pembelajaran membuat pemeranan tentang menejemen konflik menjadi sangat bermanfaat dalam menyampaikan suatu pesan moral. Khususnya tentang tanggung jawab dari setiap pribadi agar berkembang menjadi seorang wirausaha yang tangguh. Sesuai pendapat Poorman (2002), bahwa dengan strategi bermain peran yang dilaksanakan oleh guru, membuat mereka ingin terlibat aktif melakukan sesuatu dalam pembelajaran.Hal ini akan membuat mereka menjadi lebih peka terhadap masalahmasalah yang ada di sekitarnya, meningkatkan keterampilan interpersonal, dan tentu saja dapat meningkatkan keterampilan komunikasi. 


\section{SIMPULAN DAN SARAN}

Kesimpulan yang dapat diambil adalah:

1) Penggunaan metode bermain peran pada KD mengelola konflik harus diawali dengan penugasan. Penugasan tersebut dimaksudkan untuk memberikan waktu latihan kepada para siswa menghafalkan transkrip dialog, belajar mengelola mimik sesuai dengan peran, mengembangkan dialog jika diperlukan. Setelah penampilan diadakan diskusi sebagai sarana evaluasi dengan pengembangan sikap tanggung jawab siswa.

2) Penerapan metode bermain peran, diskusi,dengan penugasan dapat meningkatkan prestasi belajar kewirausahaan pada KD mengelola konflik siswa kelas XI-Teknik Pemesinan. Rata-rata meningkat 2,59 dari Prasiklus ke Siklus I, bermula dari 3,8 menjadi 6,4. Meningkat 1,34 dari 6,4 menjadi 7,7 siklus IImencapai indikator yang direncanakan, yaitu 7,5.

3) Pemeranan telah memberikan pengalaman batin sehingga sikap tanggung jawab siswa menjadi lebih baik. Hasil pengisian angket sikap tanggung jawab sebesar 95\% siswa menjadi cukup Tanggung Jawab dan sangat Tanggung Jawab secara bertahap.
Pemaknaan tanggung jawab dalam bekal berwirausaha semakin tumbuh seiring dengan pemahaman bahwa kecerdasan kognitif terhadap aspek usaha saja tidak cukup, tetapi dibutuhkan sikap yang stabil. Sebab disadari sebagian besar permasalahan dan berpotensi menimbulkan konflik disebabkan karena setiap individu atau anggota organisasi mengabaikan tanggung jawabnya.

Adapun saran dalam penelitian ini adalah sebagai berikut:

1) Penerapan metode bermain peran sebaiknya diawali dengan merumuskan transkrip dialog yang telah disepakati. Penugasan diberikan untuk memberikan waktu kepada siswa mempersiapkan diri lebih baik nantinya selama pemeranan dilaksanakan.

2) Kesulitan berbicara sesuai dialog seringkali terjadi pada kelompok yang tampil awal. Tidak mengapa jika guru membantu dengan kalimat pembuka yang dibutuhkan.

3) Penekanan sikap tanggung jawab dapat diinfilterasikan dengan tugas yang diberikan pada saat tiap kelompok siswa diharuskan menyusun transkrip dialog pemeranan yang bermuatan konflik dalam wirausaha. 
4) Kelompok siswa dalam pemeranan sebaiknya 4 sampai dengan 5 orang saja. Hal ini untuk meyakinkan agar pemeranan tidak terlalu memakan waktu yang panjang dan semua kelompok dapat tampil sesuai dengan jadwal.

\section{DAFTAR PUSTAKA}

Arikunto, Suharsimi; Suhardjono dan Supardi. 2006. Penelitian Tindakan Kelas. Jakarta: Bumi Aksara.

Cruickshank, Donald R. Jenkins, Deborah Bainer. Metcalf, Kim K. 2006. The Act of Teaching.New York, USA. McGrawHill Company, Inc.

Djamarah Syaiful Bahri, 1994. Hasil Belajar dan Kompetensi Guru. Usaha Nasional. Jakarta.

Heaton, J.B. 1991.Writing English Language Test.New Edition.Longman Handbook for Language Teachers). New York: Longman Group Ltd.

Joyce, B. R., \& Weil, M. 2000. Role Playing; Studying Social Behavior and Values.In Models of Teaching.Allyn and Bacon.

Miller, L.M. 1987.Manajemen Era Baru.Beberapa Pandangan Mengenai Perusahaan Moderen. Jakarta:Erlangga

Poorman, P. B. (2002. Biography and RolePlaying:Fostering Empathy In AbnormalPsychology. Teaching of Psychology.

Sudjana, Nana. 2001. Penelitian dan Penilaian Pendidikan. Bandug : Sinar Baru Algensindo.

Udin S Winataputra, et al.2005. Strategi Belajar Mengajar (Jakarta; Universitas Terbuka.
Winkel.1991. Psikologi Pengajaran. Jakarta: Grasindo. 
